\title{
The Armutlu Network: an investigation into the seismotectonic setting of Armutlu-Yalova-Gemlik and the surrounding regions
}

\author{
Berna Tunç ${ }^{1}{ }^{\star}$, Deniz Çaka ${ }^{1}$, Tahir Serkan Irmak ${ }^{1}$, Heiko Woith $^{2}$, Suleyman Tunç ${ }^{1}$, Şerif Bariş ${ }^{1}$, \\ Mithat Firat Özer ${ }^{1}$, Birger Gottfried Lühr ${ }^{2}$, Erwin Günther ${ }^{2}$, Helmut Grosser ${ }^{2}$, Jochen Zschau ${ }^{2}$
}

\author{
${ }^{1}$ Kocaeli University, Faculty of Engineering, Department of Geophysical Engineering, Kocaeli, Turkey \\ ${ }^{2}$ Helmholtz Centre Potsdam, GFZ German Research Centre for Geosciences, Potsdam, Germany
}

\author{
Article history \\ Received May 5, 2010; accepted November 11, 2010. \\ Subject classification: \\ Seismogical Data, Collections, Surveys, measurements and monitoring, Seismic Risk, Tectonics.
}

\section{ABSTRACT}

Armutlu Peninsula is in the Marmara Region of Turkey, located at the western end of the 1999 Kocaeli rupture. Armutlu peninsula is believed to be adjacent to the Intra-Pontide Suture Zone, or even to be a part of it. This zone has a key role for the understanding of the neo-tectonic features of this region and the interactions between high seismicity with high thermal activity and neo-tectonic faults that have originated through the ongoing movement of the two branches north and south of Armutlu. A horst and graben structure appears in this region, whereby the Armutlu Peninsula represents a horst between two branches of the North Anatolian Fault System, which results in a complex dextral zone. To understand the relationships among the micro-earthquake activity, the hydrothermal activity, and the tectonic structure of the region, the Armutlu Network (ARNET) was installed. ARNET aims to monitor the chronological evolution of the seismicity, and to investigate the deformation of the Armutlu Peninsula, and possible interactions between seismic waves and pore-pressure variations in the geothermal systems. The Armutlu-YalovaGemlik region has a very complicated tectonic structure, and it has scattered micro-earthquake activity. The upper part of the crust includes a low-velocity zone that conforms to present tectonic activity and the brittle deformed metamorphic rocks. Recent seismic activity has been confined to Gemlik Bay, and the Yalova-Termal region. Therefore, special attention is needed to monitor the seismic activity in these regions, to understand the likely and forthcoming larger event(s) in the Marmara Region. We believe that this region will have an important role in our understanding of the formation of the next larger earthquake at the western extension of the North Anatolian Fault system.

\section{Introduction}

Two main fault systems are located in Turkey, which are known as the North Anatolian Fault (NAF) and the East Anatolian Fault (EAF) systems. The NAF has a right-lateral movement, while the EAF is a left-lateral fault system. The active tectonic structure of Turkey is under the effects of these two systems, because the Anatolian Block moves towards the west at an average rate of $20-30 \mathrm{~mm} /$ year [Reilinger et al. 1997]. Over the centuries, the Marmara Region has been shaken by earthquakes of $\mathrm{M}_{\mathrm{W}}>6.5$. In 1999, two destructive earthquakes occurred in the eastern Marmara Region. The first was on August 17,1999, in Kocaeli $\left(\mathrm{M}_{\mathrm{W}}=7.4\right)$, and this was followed by the second on November 12 , 1999, in Düzce $\left(\mathrm{M}_{\mathrm{W}}=7.1\right)$. According to the official records, roughly 18,000 people lost their lives due to these two earthquakes. Some important cities, such as Istanbul, Bursa, Kocaeli, Yalova and Sakarya, are located in this region. Because of the social and economic importance, the seismic hazard of the Marmara Region is worth investigation.

\section{Regional tectonics and seismicity}

Armutlu Peninusla is situated in the eastern Marmara Region, and is located at the western end of the 1999 Kocaeli earthquake rupture; it is bound by the northern and southern branches of the NAF zone (Figure 1). The region has very complex tectonics and active seismicity.

The neotectonic period began in Anatolia by the collision of the Arabian and Eurasia plates in the Early-to-Middle Miocene [Șengör 1979, Șengör 1980, Șengör and Yilmaz 1981, Görür 1992, Y1lmaz 1992]. As a result of this collision and the crustal deformation, the East Anatolian crust thickened and the NAF and EAF systems were formed [McKenzie 1972, Dewey and Şengör 1979, Șengör 1980]. With the impact of the NAF and EAF systems and the collision, Anatolia moved westward. Associated with this movement, an extensional regime is seen in the Aegean region [McKenzie 1972, Șengör 1980, Reilinger 1997], which caused a horst and graben structure in this region, whereby the Armutlu Peninsula represents a horst between two branches of the NAF system; this has resulted in a complex dextral zone. According to Eisenlohr [1997], the active faults are Riedel shears within a 

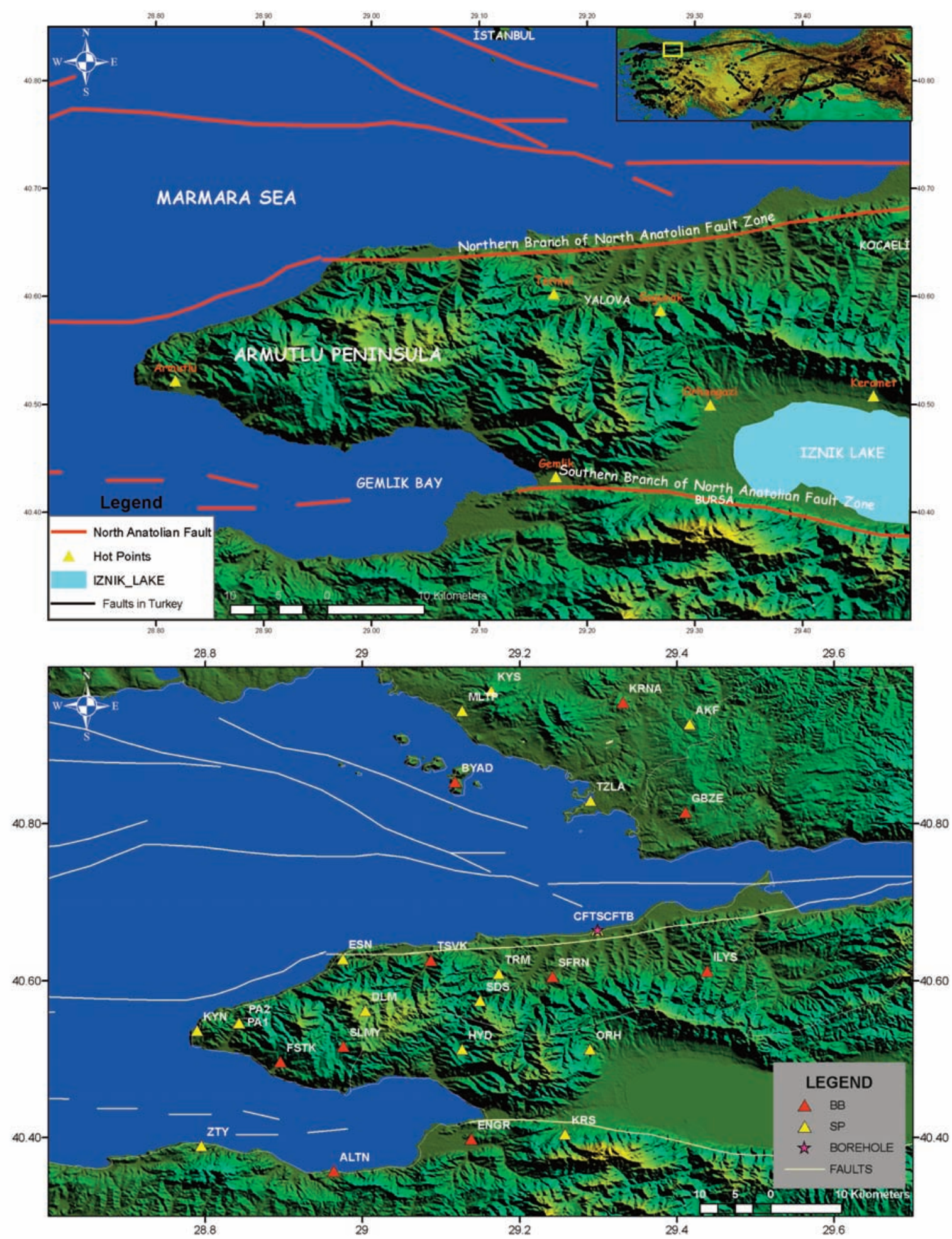

Figure 1 (top). The location of the Armutlu Peninsula. Figure 2 (bottom). Distribution of the ARNET stations. Red triangles, broad-band seismic stations; yellow triangles, short-period seismic stations; red star, borehole station; white lines, proposed active faults.

right lateral shear zone that is rotated clockwise.

Armutlu Peninsula has several geothermal areas. The hottest thermal sources are located in the north (Yalova Termal) and on the western end of the peninsula (Armutlu), and they have surface temperatures of $60^{\circ} \mathrm{C}$ to $70^{\circ} \mathrm{C}$. Other geothermal sources, of Gemlik, Orhangazi, Keramet and Soğucak, are located in the south and east of the region, and these are characterized by water temperatures of $20^{\circ} \mathrm{C}$ to $30^{\circ} \mathrm{C}$.
By associating the locations of the thermal sources with the regional faults, it can be seen that the thermal sources are related to the north and south branches of the NAF [Eisenlohr 1995].

\section{The ARNET stations}

To understand the relationships among the seismicity, hydrothermal activity, and tectonic structure of the region, the Armutlu Network (ARNET) was installed in September 


\begin{tabular}{|c|c|c|c|c|c|c|c|c|c|}
\hline No. & Station name & $\begin{array}{l}\text { Station } \\
\text { code }\end{array}$ & $\begin{array}{l}\text { Latitude } \\
\qquad\left({ }^{\circ} \mathbf{N}\right)\end{array}$ & $\begin{array}{c}\text { Longitude } \\
\left({ }^{\circ} \mathrm{E}\right)\end{array}$ & Elevation $(\mathbf{m})$ & Province & Type & $\begin{array}{c}\text { Comm. } \\
\text { type }\end{array}$ & $\begin{array}{c}\text { Vel } \\
\text { Acc } \\
\text { P }\end{array}$ \\
\hline 1 & KAYISDAGI & KYS & 40.9696500 & 29.1643000 & 429 & ISTANBUL & SP & ONLINE & VA \\
\hline 2 & AKFIRAT & $\mathrm{AKF}$ & 40.9273333 & 29.4165000 & 210 & ISTANBUL & SP & OFFLINE & $\mathrm{V}$ \\
\hline 3 & ESENKOY & ESN & 40.6280000 & 28.9751667 & 200 & YALOVA & SP & ONLINE & VA \\
\hline 4 & IHLAS POMPA1 & IPA1 & 40.5458333 & 28.8415000 & 85 & YALOVA & SP & OFFLINE & $\mathrm{P}$ \\
\hline 5 & IHLAS POMPA2 & IPA2 & 40.5465000 & 28.8430000 & 85 & YALOVA & SP & OFFLINE & $\mathrm{V} / \mathrm{P}$ \\
\hline 6 & KOYUNDERE & KYN & 40.5370000 & 28.7896667 & 48 & YALOVA & SP & OFFLINE & VA \\
\hline 7 & ORHANGAZI & $\mathrm{ORH}$ & 40.5133333 & 29.2896667 & 170 & BURSA & SP & ONLINE & VA \\
\hline 8 & KARSAK & KRS & 40.4050000 & 29.2581667 & 170 & BURSA & SP & ONLINE & VA \\
\hline 9 & ZEYTINBAGI & ZTY & 40.3900000 & 28.7948333 & 70 & BURSA & SP & ONLINE & VA \\
\hline 10 & HAYDARIYE & HYD & 40.5131667 & 29.1270000 & 390 & BURSA & SP & OFFLINE & $\mathrm{V}$ \\
\hline 11 & TERMAL & TRM & 40.6095000 & 29.1735000 & 204 & YALOVA & SP & ONLINE & $\mathrm{V}$ \\
\hline 12 & DELMECE & DLM & 40.5625600 & 29.0038800 & 728 & YALOVA & SP & OFFLINE & $\mathrm{V}$ \\
\hline 13 & KURNA & KRNA & 40.9550000 & 29.3316667 & 150 & ISTANBUL & BB & ONLINE & $\mathrm{V}$ \\
\hline 14 & GEBZE & GBZE & 40.8150000 & 29.4113333 & 200 & KOCAELI & BB & OFFLINE & $\mathrm{V}$ \\
\hline 15 & CIFTLIK (S)(brh) & CFTS & 40.6641667 & 29.2993333 & 0 & YALOVA & SP & ONLINE & VA \\
\hline 15 & CIFTLIK (B)(brh) & CFTB & 40.6641667 & 29.2993333 & 98 & YALOVA & SP & ONLINE & $\mathrm{V}$ \\
\hline 16 & SAFRAN & SFRN & 40.6061667 & 29.2418333 & 115 & YALOVA & $\mathrm{BB}$ & ONLINE & $\mathrm{V}$ \\
\hline 17 & TESVIKIYE & TSVK & 40.6266667 & 29.0873333 & 70 & YALOVA & BB & ONLINE & $\mathrm{V}$ \\
\hline 18 & ILYASKOY & ILYS & 40.6128333 & 29.4390000 & 240 & YALOVA & $\mathrm{BB}$ & ONLINE & $\mathrm{V}$ \\
\hline 19 & SELIMIYE & SLMY & 40.5168667 & 28.9757667 & 460 & YALOVA & $\mathrm{BB}$ & OFFLINE & $\mathrm{V}$ \\
\hline 20 & FISTIKLI & FSTK & 40.4975000 & 28.8955000 & 60 & YALOVA & BB & ONLINE & $\mathrm{V}$ \\
\hline 21 & ENGURUCUK & ENGR & 40.3985000 & 29.1386667 & 75 & BURSA & $\mathrm{BB}$ & ONLINE & $\mathrm{V}$ \\
\hline 22 & ALTINTAS & ALTN & 40.3578333 & 28.9638333 & 30 & BURSA & BB & ONLINE & $\mathrm{V}$ \\
\hline 23 & BUYUKADA & BYAD & 40.8538333 & 29.1181667 & 175 & ISTANBUL & BB & ONLINE & $\mathrm{V}$ \\
\hline 24 & SU DUSEN & SDS & 40.5753100 & 29.1499600 & 204 & YALOVA & SP & OFFLINE & $\mathrm{V}$ \\
\hline 25 & TUZLA & TZLA & 40.8211865 & 29.2072150 & 7 & ISTANBUL & SP & ONLINE & $\mathrm{V}$ \\
\hline 26 & MALTEPE & MLTP & 40.9440717 & 29.1268667 & 39 & ISTANBUL & SP & ONLINE & $\mathrm{V}$ \\
\hline
\end{tabular}

Table 1. List of the ARNET stations.

2005, by the Kocaeli University Earth and Space Science Research Center (ESSRC-YUBAM), in Izmit, Turkey, and in cooperation with the GeoForschungsZentrum (GFZ), the German Research Centre for Geosciences in Potsdam. Distribution of the ARNET stations on the region is shown in Figure 2. ARNET aims to monitor the chronological evolution of the seismicity, and to investigate the deformation of the Armutlu Peninsula, as well as the possible interactions between seismic waves and pore-pressure variations in the geothermal systems.

Within the geothermal field of Armutlu, the fluidpressure changes of a 500-m-deep artesian well are monitored at a rate of $100 \mathrm{~Hz}$ to determine the relation between the micro-earthquake activities and the hydrothermal reservoir properties. Additionally, the water levels and water temperatures are monitored in several wells and natural 


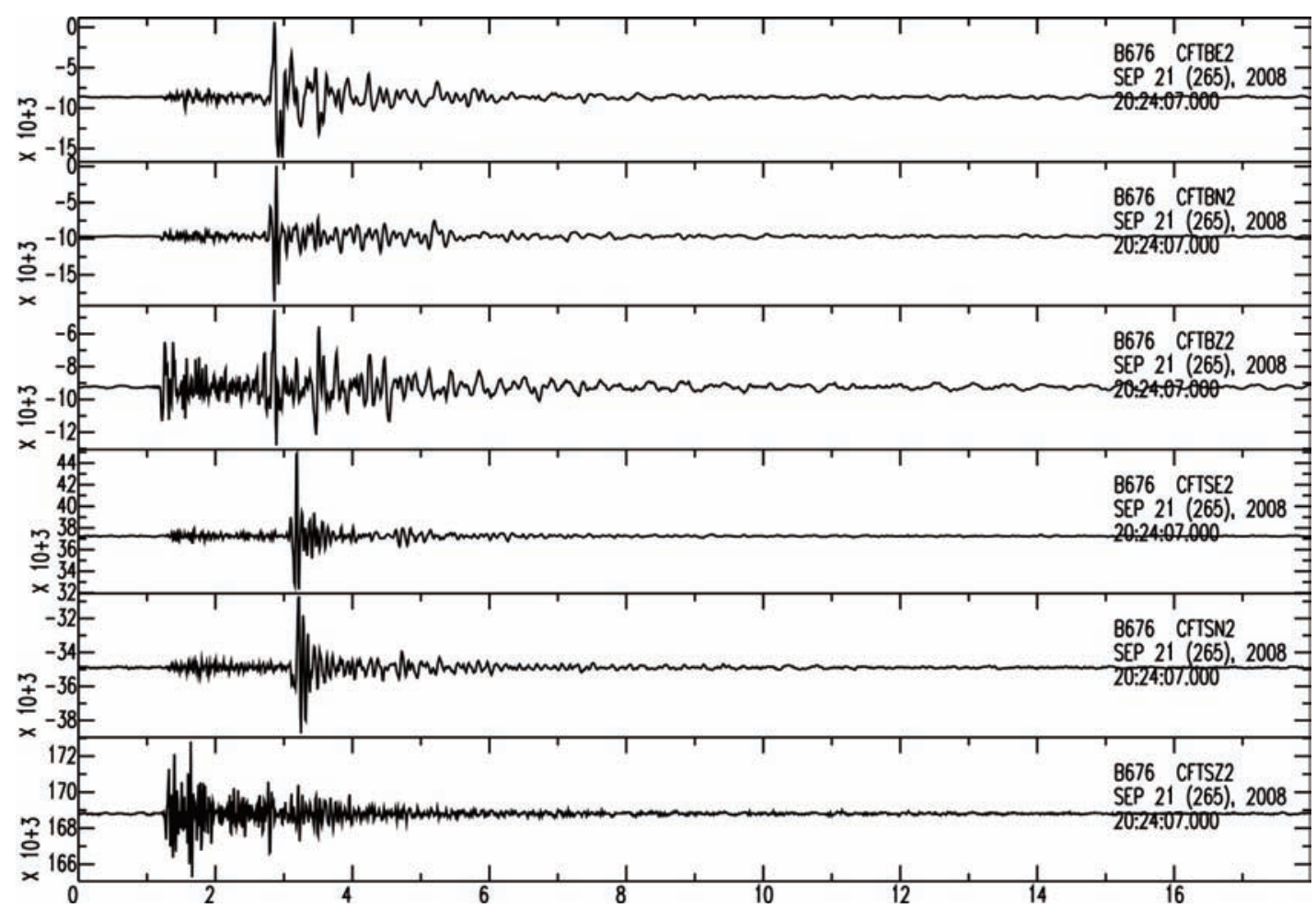

Figure 3. First records of the borehole station CFTB (borehole) and CFTS (surface). The earthquake occurred on September 21, 2008, at 20:24:07:00.

springs around the Armutlu Peninsula.

ARNET consists of 25 seismic stations and 1 hydrothermal station (IPA1) in and around the Armutlu Peninsula (Table 1). The network is composed of 26 weakmotion seismometers (16 short period [SP]; 10 broad-band $[\mathrm{BB}])$ and 6 accelerometers. To avoid the clipping problem, we installed the accelerometers at the stations that are close to the faults. For the SP seismometers, the Reftek digitizers were replaced with Guralp digitizers in 2009. This change improved the network reliability and resolution considerably. Data processing for the 2009 data has still been continuing. The bandwidth for the SP seismometers is $1 \mathrm{~Hz}$ to $50 \mathrm{~Hz}$, for the $\mathrm{BB}$ seismometers, $0.033 \mathrm{~Hz}$ to $50 \mathrm{~Hz}$, and for accelerometers, DC-100 Hz. At Ciftlik station, a Lennartz Le3Dlite borehole seismometer was installed at a depth of 98 $\mathrm{m}$, in 2008. Two types of instruments are installed at this station. One is a SP seismometer (Lennartz Borehole) (CFTB) and the other is an accelerometer at the surface above the well (Guralp CMG5T accelerometer) (CFTS). In Figure 3, the first record of the borehole station is shown.

At present, the study area is being monitoring by a total of 25 seismic land stations, with 18 stations accessible online. The data are transferred via ADSL to Kocaeli University. Currently, we are installing online communication systems in the remaining stations of our network. A sample sketch of the communication system is shown in Figure 4 for the borehole station. At all of the online stations, we can control the digitizer, data communication module, and ADSL modem by power-cycles over the phone lines, using a dualtone multi-frequency controller.

\section{Data processing}

The phase readings obtained from the network are performed by the zSacWin algorithm at the ESSRC. The zSacWin algorithm was developed for determination of the $\mathrm{P}$-wave and S-wave arrival times and earthquake parameters by M. Yllmazer (2007, personal communication). The algorithm was obtained through mutual meetings. As well as the $\mathrm{P}$-wave and $\mathrm{S}$-wave arrival times, using this algorithm, earthquake parameters can be obtained, such as the origin time, depth, location, magnitude and focal mechanism. After this process, the data are backed up on hard discs in SAC, MiniSEED and GCF continuous format. Our catalog includes data since 2005, while the phase readings of the data until the end of 2008 are completed, and the manual picking and phase readings are still continuing. As of today, a good quality dataset is available for the Armutlu Peninsula and its surroundings.

In September 2009, we also installed the final version of the SeisComp3 software for data acquisition and automatic location procedures. The software was developed for the GEOFON network. Various versions of this have been used widely all over the World. SeisComp3 provides data acquisition, data quality control, real-time data exchange, network status monitoring, real-data processing, event alerts, waveform archiving, waveform data distribution, automatic event detection and location, interactive event detection and location, event parameter archiving, and easy access to the relevant information about stations, waveforms and recent earthquakes. The SeisComp3 system contributes to faster data processing, although it is still in a testing phase for 


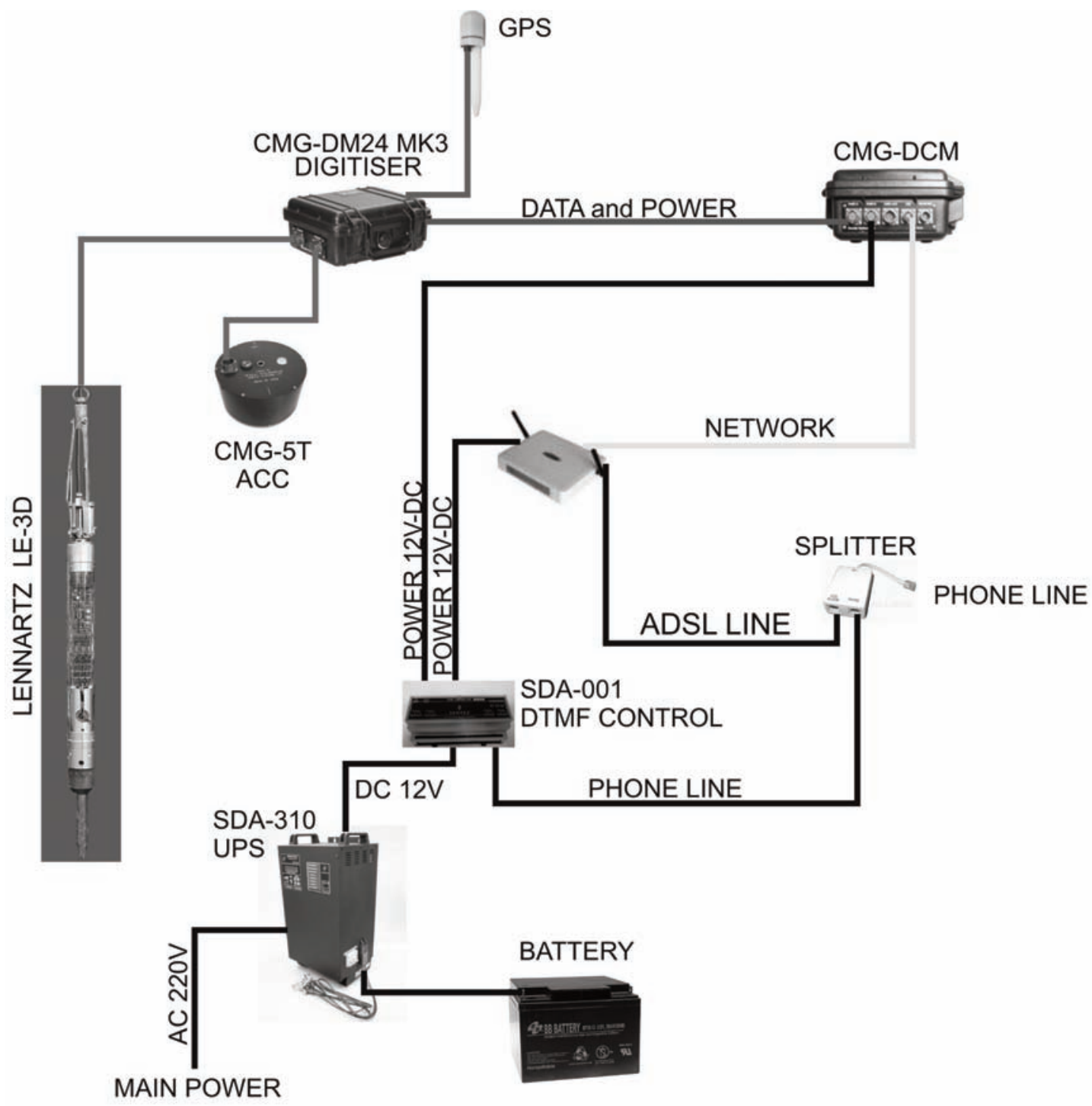

Figure 4. A sample installation chart of the borehole seismometer in Ciftlik station (CFTS-CFTB).

ARNET. We are also trying to implement the automatic picking procedures of SeisComp3 in our center, to locate offline datasets.

\section{Results}

According to historical large events and the present seismicity data, the Marmara Region appears to be one of the most active regions in Turkey. After the 1999 earthquakes (August 17,1999, in Kocaeli, and November 12, 1999, in Duzce), and because of the after-shocks, the seismicity has significantly increased in the Marmara Region. The aftershock activity continued over 3 years after the main shocks, and the Armutlu Peninsula has also been affected by these earthquake activities. Preliminary investigation of the microearthquake activity of this region shows that the (present) seismic activity increased after the 1999 events for the western part of the 1999 rupture zone, while the rupture zone itself is now quiet. In Figures 5 and 6, the seismicity of the Armutlu Peninsula and its surroundings is shown for different time periods. To eliminate the effects of after- shocks, the data between 2002 and 2009 were used for Figures 5 and 6, with the time periods selected as January 2002 to May 2005, and June 2005 to December 2009, to illustrate the increase in the seismicity of the Armutlu Peninsula. The second period covers the ARNET data period. The data used in Figures 5 and 6 were been obtained from the Boğaziçi University, Kandilli Observatory and Earthquake Research Institute, National Earthquake Monitoring Center (BU-KOERI-NEMC) catalogs. When we compare Figures 5 and 6 , it can be seen that the seismicity in the second period is higher than in the first period.

We recorded 2,894 events during the study period. The Armutlu Peninsula has a relatively high micro-earthquake activity (Figure 7). This micro-earthquake activity shows some clusters, although most of the micro-earthquakes are unexpectedly scattered. These clusters are also seen in Figure 6, as obtained for the ARNET dataset. As seen in Figure 7, our results are in good agreement with the KOERI data plotting. This region is highly deformed, with many small and medium-sized faults. The tectonic structure, geology 

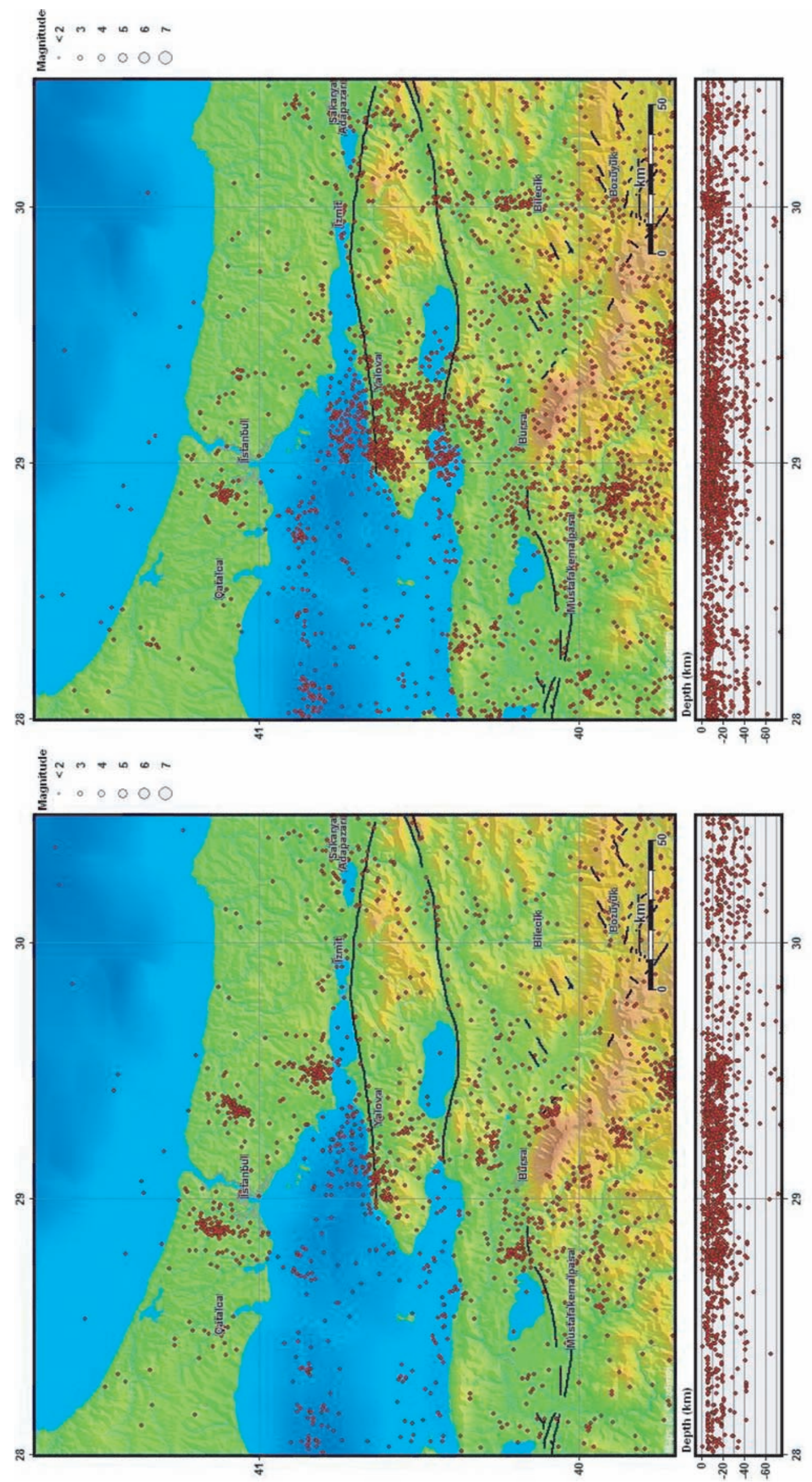


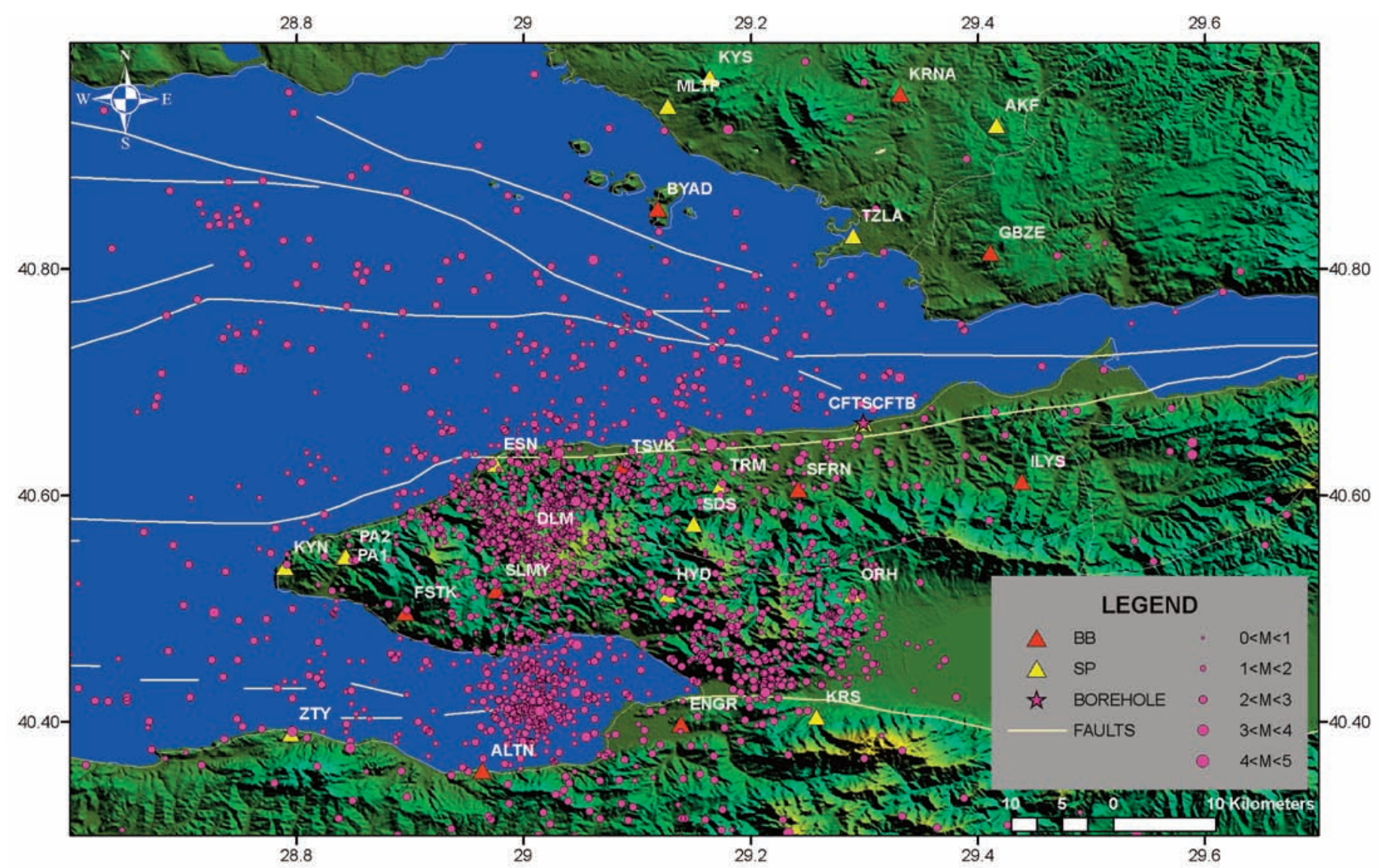

Figure 7. Seismicity of the Armutlu Peninsula. The earthquakes were recorded by the ARNET stations between October 2005 and August 2007 , and from July to September 2009. Symbols as for Figure 2.

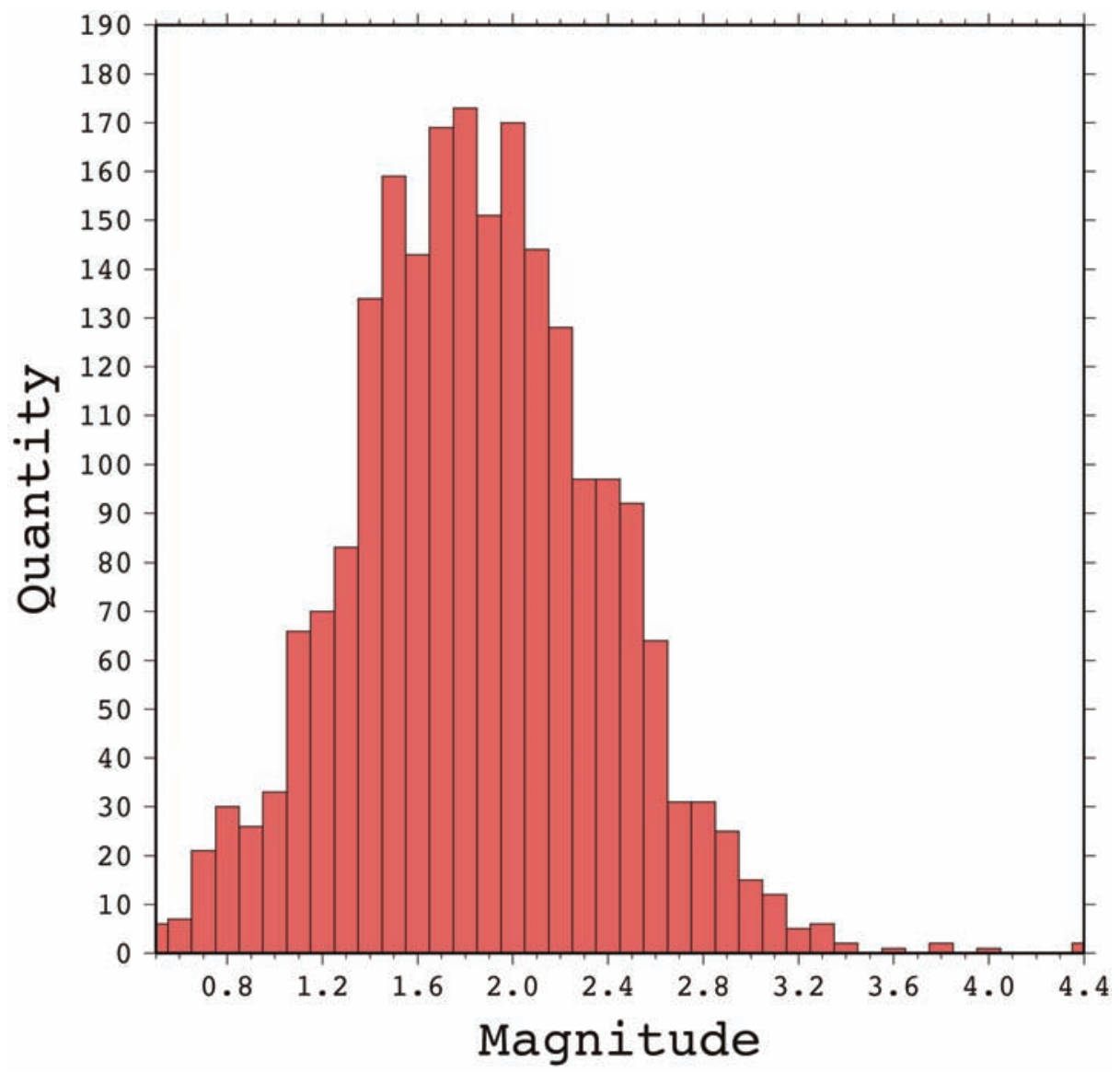

Figure 8. Histogram for the Armutlu Peninsula dataset. 


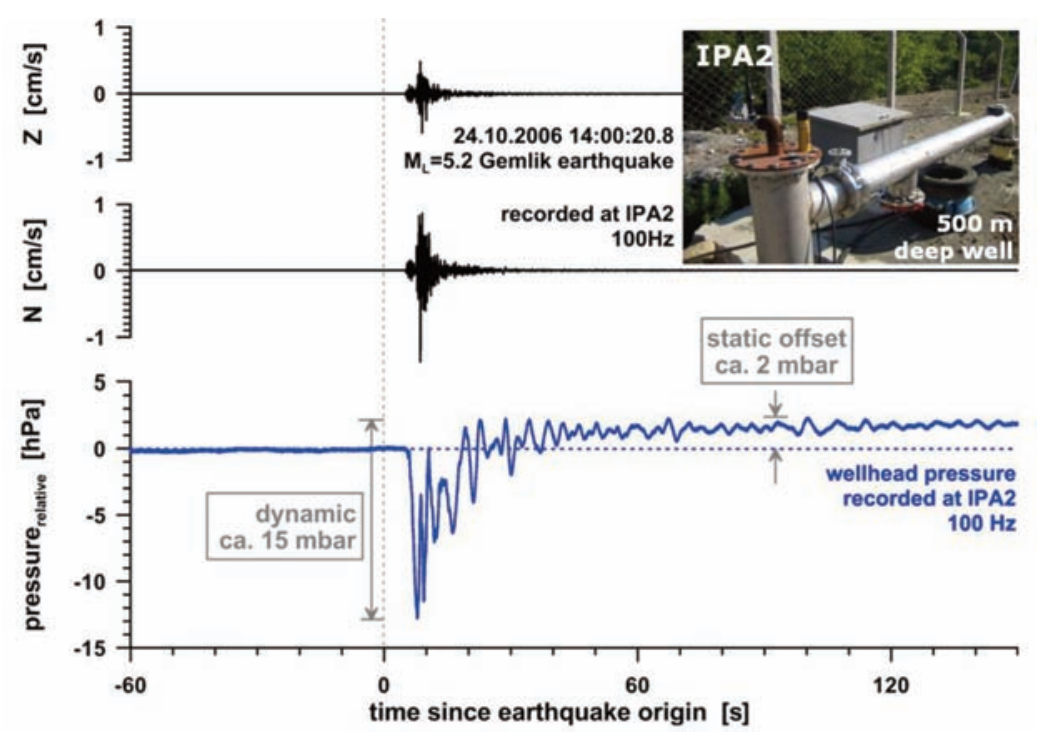

Figure 9. An example of the dynamic and static pressure changes in a well recorded for the thermal field of Armutlu after the $\mathrm{M}_{\mathrm{L}}=5.2 \mathrm{Gemlik}$ earthquake.
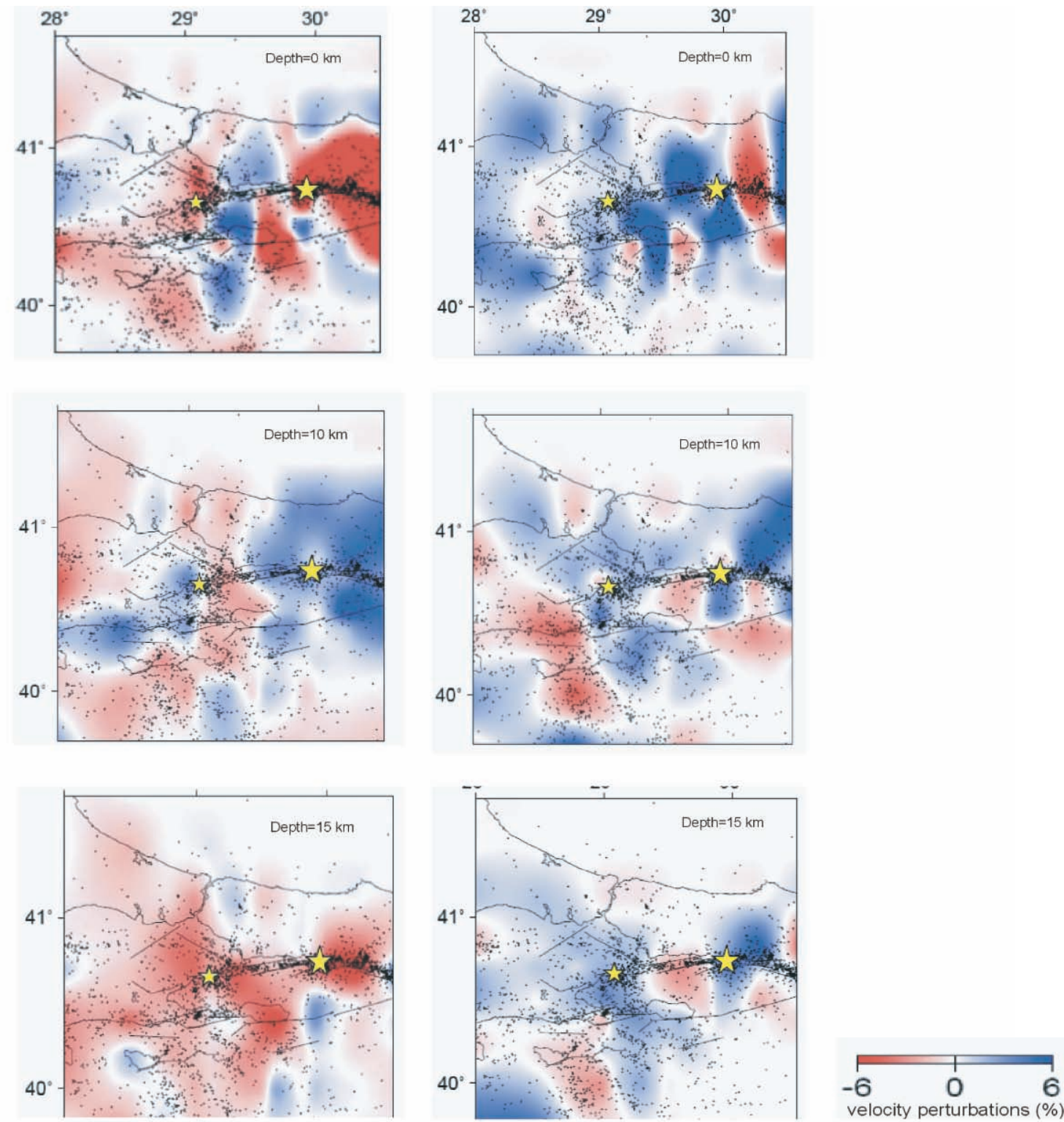

Figure 10. Velocity perturbations (\%) after tomographic inversion of the P-waves (left) and S-waves (right). Blue and red, high and low velocity perturbations, respectively; black lines, faults; dots, epicenters of micro-earthquakes; large and small yellow stars, the August 17, 1999, Kocaeli earthquake $(M=7.4)$, and one of the biggest after-shocks, which occurred on August 19, 1999 ( $M=5)$, respectively [Aslan 2008]. Depths as indicated. 


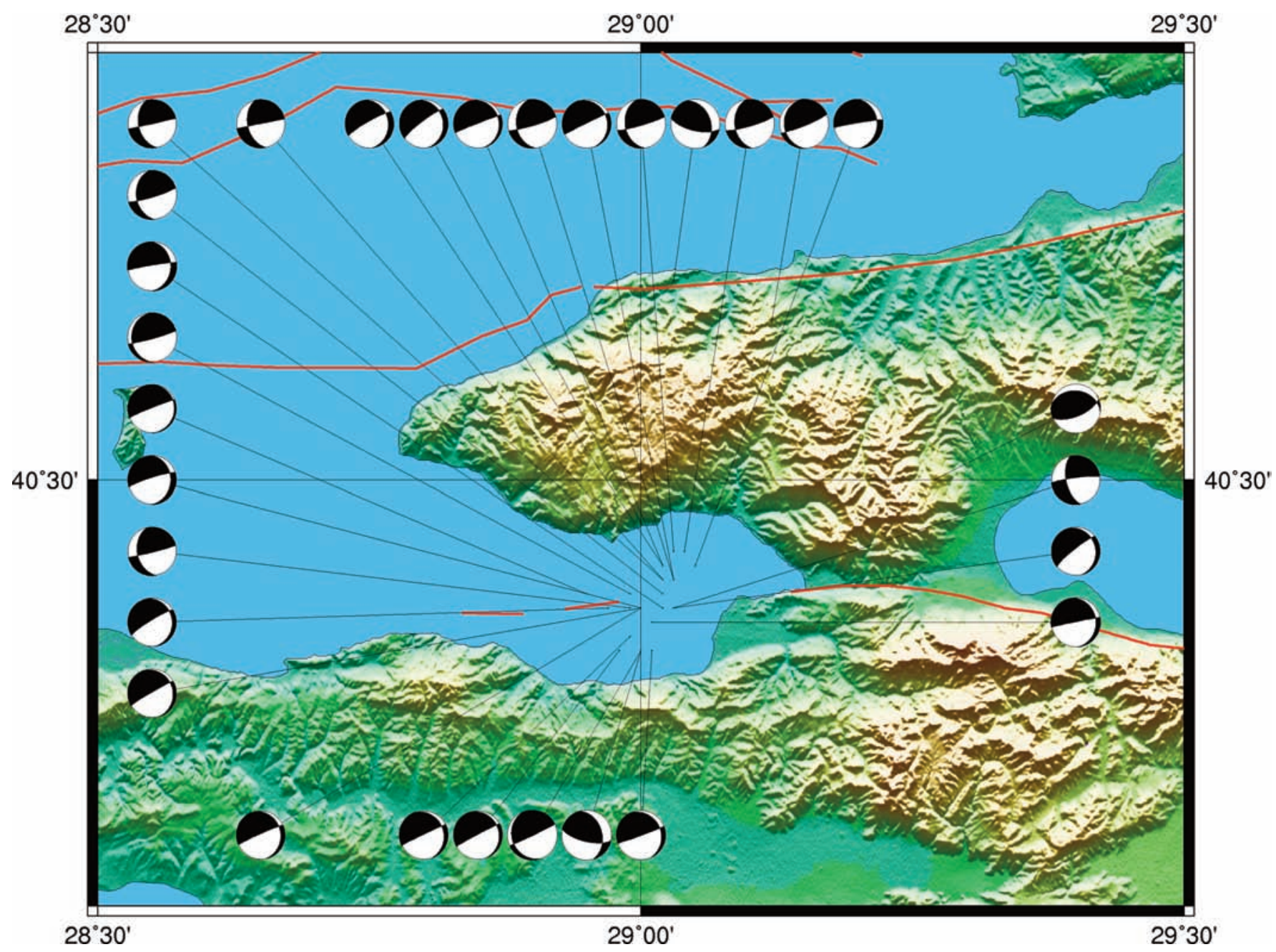

Figure 11. Focal mechanisms of some of the earthquakes.

and aging of the rock are still under discussion, and there is no consensus about them. We believe that this region has very complex tectonic features, and thus its seismicity does not show clear clustering and alignment along the wellknown fault traces.

A histogram for the Armutlu Peninsula and its surroundings is shown in Figure 8, where the earthquakes recorded by ARNET between 2005 and 2007 and for 3 months of 2009 are included. The magnitudes are limited between $0.5 \mathrm{Mb}$ and $4.4 \mathrm{Mb}$. Most of the magnitudes of the detected events are in the range between $1.0 \mathrm{Mb}$ and $3.0 \mathrm{Mb}$. There are six earthquakes with magnitudes smaller than 0.5 $\mathrm{Mb}$. In addition these, an earthquake occurred in Gemlik on October 22, 2006, at 14:00:21, as $\mathrm{M}_{\mathrm{L}}=5.2$. These earthquakes are not shown in the histogram because of the gap between the smallest and largest magnitudes.

At station IPA2, a pressure sensor and a surface seismometer are installed. The pressure sensor is located at the well-head of the 500-m-deep well (Figure 9). In Figure 8, the upper two signals represent the vertical $(Z)$ and the north-south (NS) components that are recorded by the SP seismometer. The bottom signal represents the pressure changes recorded by the pressure sensor in response to the $\mathrm{M}_{\mathrm{L}}=5.2 \mathrm{Gemlik}$ earthquake, which occurred about $20 \mathrm{~km}$ from the monitoring site.

We observed similar pore pressure variations relating to the $\mathrm{M}_{\mathrm{L}}=5.2$ event, which occurred at about $70 \mathrm{~km}$ (Manyas earthquake of October 20, 2006). In both cases, the dynamic pressure oscillations are followed by a static increase in the pressure, which remains after the seismic waves have passed the geothermal system. The physical mechanism for the static pressure increase is not understood at present.

A tomographic study was carried out for the region by Aslan [2008]. Tomographic results of this study is given in Figure 10 for the P-waves (left) and S-waves (right). The dataset used in this study contains micro-earthquake activity that includes after-shocks since 1993, recorded by the BUKOERI. To increase the resolution, some of the earthquake arrival times recorded by ARNET have been added to the KOERI dataset, using the TOMOG3D algorithm developed by Zhao et al. [1992].

The results of the study are largely in agreement with other tomography studies for the Marmara Region [Nakamura et al. 2002, Bariş et al. 2005, Tunç 2008]. For 
tomographic inversion studies, the distribution of the earthquakes and the station coverage have key roles in the resolution. Therefore, fewer, but good quality and well distributed, earthquakes are better for good results. The ARNET data are suitable for tomographic inversion because of their quality and locality, and the good distribution of the ARNET stations. Tomographic inversion for the Armutlu Peninsula and its surroundings was started using the ARNET data. The ongoing study is being carried out using the LOTOS-10 algorithm and only the ARNET data. The LOTOS algorithm was developed by Koulakov et al. [2006] for simultaneous inversion of P-wave and S-wave velocity structures and source coordinates, and it has some advantages, such as determination of the one-dimensional velocity model, high resolution, and testing options.

Another ongoing study is the focal mechanism solutions of the earthquakes in and around the Armutlu Peninsula. In Figure 11, the after-shocks of the Gemlik earthquake $\left(\mathrm{M}_{\mathrm{L}}=\right.$ 5.2) of October 24, 2006, are shown. As seen in Figure 11, these are mainly right-lateral strike-slip faulting and partly normal and reverse faulting. This distribution of the focal mechanisms supports the opinion of the complexity of the tectonics around the region.

\section{Conclusions}

The Armutlu region has a very complicated tectonic structure, and it is presently characterized by diffuse microearthquake activity. Due to the active tectonic features of this region, a huge number of earthquakes have been recorded by the network. One of the main contributions of ARNET is to obtain a good quality dataset for the eastern Marmara Region. This dataset contains the phase readings of the earthquakes between 2005 and 2008, and raw data from 2005 to the present. The picking of the earthquakes from 2008 to the present is still continuing.

To improve the accuracy of our models and results, we have to analyze more earthquake data and we have to improve the one-dimensional and three-dimensional velocity models by using data from quarry blasts or by conducting seismic experiments. The recent seismic activity has been confined to Gemlik Bay, and the Yalova-Termal region. Special attention is needed to monitor the seismic activity in this regions, to be able to understand the likely and forthcoming larger event(s) in the Marmara Region. We believe that this region will have an important role in the understanding of the formation of the next larger earthquake at the western extension of the 1999 rupture. Due to the complex tectonic features, the seismicity does not show clearly defined clustering along alignments of (known) fault traces. We suggest that micro-earthquake monitoring should be continued, and that the hypocenter location techniques as well as the three-dimensional crustal structure models for this study region should be improved.
The results of the tomography study indicate that the upper part of the crust shows low-velocity zones that conform to the present tectonic activity and brittle deformed metamorphic rocks. The images show an area of strong velocity heterogeneities in both the horizontal and the vertical directions, caused by fractures and the fissured structure of a fault zone area. In general, low-velocity zones are found in the western part of the Armutlu Peninsula and the adjacent Marmara Sea, whereas relatively high velocity zones are found around Geyve and the Izmit Gulf. Local tomography studies should be repeated with better datasets and new algorithms.

Ongoing studies on the focal mechanisms indicate that the earthquakes are dominated by strike-slip and normal faulting (or a combination of both), which supports the idea of a complex fracture system that leads to scattered earthquake clusters and strong hydrothermal activity in the study area.

Acknowledgments. Many thanks to KOU-ESSRC and GFZ-Section 2.1: Earthquake Risk and Early Warning staff and students for their contributions to the data processing. Many thanks to Kocaeli University Rectorate for the contributions to the field study. This sudy is supported by the Kocaeli University Scientific Research Project Unit, under the project «Observing Micro-Earthquake Activity and Cluster Stress Distribution of the Armutlu Peninsula», 2008/33.

\section{References}

Aslan, Ö. (2008). Three-dimensional seismic velocity structure of the Armutlu-Gemlik surroundings, Masters Thesis, Kocaeli University, (in Turkish).

Barış, S., J. Nakajima, A. Hasegawa, Y. Honkura, A. Ito and S.B. Üçer. (2005). Three-dimensional structure of Vp, Vs and $\mathrm{Vp} / \mathrm{Vs}$ in the upper crust of the Marmara Region, NW Turkey, Earth Planets Space, 57, 1019-1038.

Dewey, J.F. and A.M.C. Șengör (1979). Aegean and surrounding regions: complex multi-plate and continuum tectonics in a convergent zone, Geol. Soc. Am. Bull., 90 (1), 84-92.

Eisenlohr, T. (1997). The thermal springs of the Armutlu Peninsula (NW Turkey) and their relationship to geology and tectonic, In: Active Tectonics of Northwestern Anatolia The Marmara Poly-Project, edited by C. Schindler and M. Pfister, Zürich, vdf, Hochschulver. an der ETH-Zürich, 197-228.

Görür, N. (1992). A tectonically controlled alluvial fan which developed into a marine fan-delta basin at a complex triple junction: Miocene Gildirli formation of the Adana Basin, Turkey, Sediment. Geol., 81, 243-252.

Koulakov, I., S.V. Sobolev and G. Asch (2006). P and S velocity images of the litosphere-astenosphere system in the central Andes from local-source tomographic inversion, Geophys. J. Int., 167, 106-126.

McKenzie, D. (1972). Active tectonics of the Mediterranean region, Geophys. J. Roy. Astr. Soc., 30, 109-185.

Nakamura, A., A. Hasegawa, A. Ito, B. Üçer, Ș. Barış, Y. Hon- 
kura, T. Kono, S. Hori, R. Pektaş, T. Komut, C. Çelik and A. M. Işıkara (2002). P-wave velocity structure of the crust and its relationship to the occurrence of the 1999 Izmit, Turkey, earthquake and aftershocks, B. Seismol. Soc. Am., 92, 330-338.

Reilinger, R.E., S.C. McClusky, M.B. Oral, R. King, M.N. Toksöz, A. Barka, I. Kinik, O. Lenk and I. Sanlı (1997). Global positioning system measurements of present day crustal movements in the Arabia-Africa-Eurosia plate collision zone, J. Geophys. Res., 102, 9983-9999.

Șengör, A.M.C. (1979). The North Anatolian tranform fault: its age, ofset and tectonic significance, J. Geol. Soc. London, 136, 269-282.

Şengör, A.M.C. (1980). Türkiye'nin Neotektoniğinin Esasları', Türkiye Jeol. Kurumu Konf., 2, 40.

Șengör, A.M.C. and Y. Y1lmaz (1981). Tethyan evolution of Turkey: a plate tectonic approach, Tectonophysics, 75, 181-241.

Tunç, B. (2008). Determination of the three-dimensional velocity structure of the Marmara Region by tomographic methods, PhD Thesis, Kocaeli University, (in Turkish).

Yilmaz, Y. (1992). New evidence and model on the evolution of the southeast Anatolian orogen, Geol. Soc. Am. Bull., 105, 251-271.

Zhao, D., A. Hasegawa and S. Horiuchi (1992). Tomographic Imaging of P and S Wave Velocity Structure Beneath Northeastern Japan, J. Geophys. Res., 97 (B13), 19909-19928.

${ }^{\star}$ Corresponding author: Berna Tunç,

Kocaeli University, Faculty of Engineering, Dep. of Geophysical

Engineering, Kocaeli, Turkey; e-mail: berna@kocaeli.edu.tr.

C 2011 by the Istituto Nazionale di Geofisica e Vulcanologia. All rights reserved. 